\title{
Beyond Conflicts, the Misrepresentation of Ethnicity in Contemporary Nigeria
}

\author{
Mustapha Salihu, PhD Candidate \\ Yahaya Yakubu \\ Nile University of Nigeria, Nigeria
}

Doi: 10.19044/elp.v7no4a3 㞷L:http://dx.doi.org/10.19044/elp.v7no4a3

\begin{abstract}
Within the literature on ethnicity, the predisposition to amplify the conflictual dimensions of ethnicity at the expense of its competitive and cooperative properties has gained considerable audience. Often than not, heightened levels of ethnic consciousness are closely associated with the inability of indigenous ethnic groups in Nigerian to attain commendable level of integration. Given its centrifugal role in informing competition for resource, political power as well as its collective action properties, it is imperative to extend research on ethnicity beyond its potency for driving conflictual group relations. Building on the submissions of ethnic competition theorists, the study concludes; ethnic in its symbolic and instrumental dimensions, are not spontaneous, and as such insufficient in accounting for the prevalence of intergroup conflict. Rather, the research acknowledges the role of ethnic entrepreneurs who pursue their personal and in other times group aspirations by mobilizing ethnic consciousness for conflictual ends. Resultantly, the study blames ethnic entrepreneurs and not ethnic consciousness for prevailing conflictual relations amongst ethnic groups. Moving on, the study advocates the need for objective analysis of ethnicity beyond its potency for mobilizing conflictual group relation.
\end{abstract}

Keywords: Ethnic-Civic Citizen, Ethnic Conflict, Ethnic Competition Model, Ethnic Mobilization, Ethnic Misrepresentation and Ethnic Entrepreneurs.

\section{Introduction}

In the formative phase of the Nigerian state, concerns for national unity assumed secondary status; colonial elites championed their personal and regional interests over nation building (Franca and Omolulo, 2011; Osagha et al, 2005; Diamond 1987). For many, there existed not a feeling of collective identity in relation to the political community to which they belong too. As such, what passed for nationalism, during the anti-colonial struggle, were 
arguably shared aspirations for self-actualization by various sub-national groups (Oluwaseun, 2015). Furthermore, indigenous ethnic groups became exposed to one another, in terms of self-government and administration, in the terminal period of colonial rule (Alapiki, 2005; Duruji, 2014; Alesina, Easterly and Matuszesky, 2010). The colonial policy of amalgamation was not only autocratic (Ray, 2012); it set the tone for fractionalization of the Nigerian state into two publics, the civic and ethnic citizen (Mandani, 1996; Ekeh, 1975). This civic identity fell short of popular acceptance, the ethnic citizen on the other hand was not only established, indigenous groups tied it to their ancestral origin (Dibua, 2011).

The intersecting roles of ethnic-civic citizen, plays a significant role in political mobilization and leadership, as well as intersection of ethnicity with religion, and the reduction of intricate geo-strategic and historic conflicts to ethnic strife (Naysan and Mariz, 2016; Remi and Adeline, 2016). Decades after independence, Nigeria is defined by far reaching division, as a result of the conscious decision to compete for power and decision making over economic resources along ethnic and religious divides (Ray, 2012; Marie and Robinson, 2011). Arguably, the challenges associated with managing her diverse ethnic and religious difference in reconciliation to civic patrotism remains one of her foremost undoing (Daniel, 2011; Imuetiyen, 2015). In Nigeria, ethnicity is central to individual identity in relation to groups (Adeboye and Omilusi, 2015; Imuetinyen, 2015; Ukiwo, 2005), and has since become a major variable of the nation's political life (Imuetinyen, 2015; Mbalisi, 2017; Remi et al, 2016).

Regrettably, the complexities that characterizes the unhealthy nature of competition amongst underlying ethnic groups has in other times resulted in discriminate sectarian violence1. In all, credible observers trace over three hundred thousand deaths since 1999 to ethnic, religious, and sectarian conflict in Nigeria (John, 2010). Hence, it is not unexpected that ethnicity is vilified as the bane of all vices in contemporary Nigeria (Olayode, 2016; Peter, Yetunde \& Folarin, 2014, p. 70). Against this backdrop, it is imperative to examine the fondness for amplifying the conflictual tendencies of ethnicity at the expense of its corporative and competitive dimensions. Building on competitive ethnic model (Ozlak, 1982 and Barth 1969), the propositions guiding this literary exercise states that;

I. In the absence of competition for resource and political power, ethnic remains largely non-conflictual. More than often, the manifestation of conflictual ethnic relations in Nigeria, are deliberate decision by ethnic entrepreneurs to pursue individual/group aspirations through violent means.

\section{Methodology}


The adoption of qualitative method of social inquiry, necessitates the reliance on secondary literature. The choice of method is informed by the inability to directly observe the phenomena under examination. Thus, the study relies on diverse conceptual and theoretical submissions, upon which inference are made and conclusion are drawn (Johnston, 2014). In a time where infinite volumes of data are being collected and archived by researchers all over the world, the practicality of utilizing existing data for research is becoming more prevalent (Andrews, Higgins, Andrews, Lalor, 2012). The use of existing data sets does not only fast-track the pace of research; it eliminates the challenges of cost, time and measurement associated with primary data collection (Doolan \& Froelicher, 2009). The material for analysis includes; peer reviewed journal publications, texts, and periodic journals amongst other secondary sources as required.

\section{Ethnicity in Contemporary Nigeria}

Intensified levels of ethnic awareness in Nigeria (Adetoye, 2015; Yakubu, 2018), is not a new phenomenon, they were activated long before independence (Alapiki, 2005, p. 50). The arbitrary mashing up of indegenous ethnic groups in Nigeria into a centralist structure, implies that competition for resources and economic decision making centers around the three major ethnic groups (Hausa, Yoruba and Igbo) jointly encompassing two thirds of Nigeria's population (Horowitz, 1971). A variety of factors informed the competition amongst the three dominant ethnic groups in Nigeria. In amongst others, they include; increased socialization among and within regions, enlargement of the political arena to accommodate alternative opinions, and the engineering of Nigerian politics around ethno-regional partisanship (Melson et al, , 1971). It has also been argued that, ethnic conflict in Nigeria are less likely to be brought about by primordial antagonism. Rather, they are more likely to have been informed by the economic and political competition (Ozlak and Nagel, 1982). In amongst other structural factors, ethnic consciousness in Nigeria is predominantly informed by state institutions, religious institutions, sociocultural groups and others, which allows for conscious self-identification and affirmative recognition by others (Ukiwo, 2005). And escalated according to ( Ayatse and Akwu, 2013; Ozlak, 1983) by rapid increase in urbanization, which implies that ethnic citiens who identify with different ethnic groups compete for scarce resources in the same environments. This arguably gave rise to social organizations to which ancestral descent was prerequisite for membership, many of which have since become formalized, who responded to the needs of their members. On this note, Brubaker et al (2004) emphasizes the challenge of reducing ethnicity to "shared traits or cultural commonalities", which in actual terms are outcomes of the interaction between external forces that enforce categorization and self-identification. 
For Chief Obafemi Awolowo, Nigeria to a greater extent remains a distinctive communicative description to distinguish those who live within the boundaries of Nigeria from those who do not (Aghamelu and Aghamelu, 2016, p. 136). In actual terms, the state (region) from which one comes from is central to accessing public goods and services. The institutionalized quota based systems in Nigeria, demands that even admission to tetiary institutions are determined by quota alloted to one's state of origin (Vanguard Editorial, November 27, 2011; p. 1). According to (Osagha et al, 2005; Diamond 1987), no nation embodies the political explosiveness and human misfortune of competitive ethnic mobilization than Nigeria in the first decade of postindependence. While Ilorah (2009) is of the opinion that, leadership in such countries tend to be bias, and citizens are subjected to unequally treatment by states and their numerous institutions, more so in the areas of resource allocation and political representation (Caselli and Coleman, 2006; Padro i, 2007).

In amongst other structural factors, ethnic consciousness in Nigeria is predominantly driven by structural, religious and socio-economic constraints, which sanctions conscious self-identification and affirmative recognition by others (Ukiwo, 2005). According to, (Ayatse and Akwu, 2013; Ozlak, 1983) these trend is exuberated by rapid urbanization, which implies that ethnic citiens who identify with different ethnic groups compete for scarce resources in the same environments. This arguably gave rise to social organizations to which ancestral descent was prerequisite for membership, many of which have since become formalized, who responded to the needs of their members. On this note, Brubaker et al (2004) emphasizes the challenge of reducing ethnicity to "shared traits or cultural commonalities", which in actual terms are outcomes of the interaction between external forces that enforce categorization and self-identification.

Against this backdrop, it is the view of this study that ethnicity in Nigeria derives in amongst other factors; the mobiliation of primordial sentiments on the basis of shared mutual ancestry, dialect and belief systems, for the purpose of socio-economic and political contestations. The symbolism ascribed to group membership based on mutual attributes, historical and cultural heritage are transformed into realities capable of enlisting members to support group action (Vermeersh, 2011; Akidiyo, 2013). Within this line of thought, the ethnic variable may be sufficient in informing conflictual relations amongst competing groups, it however not a prerequisiteis not a necessary condition. Ethnic conflicts are not spontaneous neither are they indiscriminate, they need certain degree of mutual belongingness and mobilization, put differently it involves organization and planning. Given this, the study presupposes that, ethnic conflicts manifests when a critical number of influential people undertake deliberately to pursue their goals or that of the 
groups through violent (Wolff, 2007, p. 6; Kalu, 2016). Such a decision may derive from history of inter-group competition for socio-economic and political interests. The aforementioned process is herewith referred to as ethnic mobilization. The roles of ethnic entrepreneurs in the mobilization process, remains central to transforming symbolic identities into podia's for conflictual, competitive and coperative ends (Nulifer and Romine, 2015).

The inability of the Nigerian state, to effectively manage or integrate indigenous groups (Kalu, 2016; Patrick et al, 2014), and to equitably redistribute resources, wealth and political is arguably the basis for conflicting group relations and not ethnicity. However, in the absence of viable class structures, ethnic entreprenuers exploit the solidarity inherent in ethnic concious to pitch one group against the other. To highlight non-conflictual manifestation of ethnicity in Nigeria, subsequent sections examines the submission of the ethnic competition model.

\section{How Conflictual is Ethnicity?}

Conflict remains of one the salient outcomes of man's continuous attempt at communal living. It is not confined to any singular region and can be informed by a handful of factors. Although they tend to be more pronounced in emerging nations, given the frequencies at which they occur Adetoye and Omilusi (2015) argue that conflict necessitates struggle and rivalry for objects to which individuals and groups attach importance. Similarly, Osaghae and Suberu (2005) are of the view that material objects in relation to conflict may include scarce resources like money, employment, and position including political ones. Further highlighting the non-material objects to include culture, tradition, religion and language. The identity of conflicting parties, degree of contestations, and subjects of contestations may also be subjected to contestation over time. Hence, conflicts are dynamic as they escalate and de-escalate, and are constituted by a complex interplay of attitudes and behavior that can assume a reality of their own (Aghamelu et al, 2016). For to Lincoln et al (1997) conflict is a vigorous process that passes through classifiable phases. The first three phases of conflict include; dispute (disagreements), conflict (use of force or violence), hostilities (fighting between organized units) and the fourth "cessation of hostilities" (armed truce). In this phase, the conflict and the dispute are still unresolved. In the fifth phase, "beyond conflict", the conflict is no longer perceived in military terms, but it is not over and the dispute persists.

Keeping in mind the multi-layered and relative understanding of conflict, the study holds that ethnic conflict prevails in instances where opposing groups may define themselves on the basis of shared dialect, culture, territorial proximity and common ancestry or even incompatible interest in amongst others. Building on the symbolic understanding of ethnicity (which 
upholds ethnic as the base for group identity), the study is of the view that ethnicity in itself is not inherently conflictual; however, it can be mobilized for conflictual ends. The implications of this assumption, dictates that, ethnicity prior to mobilization for group action or competition in relation to social, political or economic dimension, should at the least meet certain prerequisites which may include but not limited to source for group identity and differentiation on the basis of shared value and belief systems.

Contextually, it is believed that intensified consciousness of the ethnic citizen in societies with weak class structures, has in collaboration structural bias and exclusionary leadership, perceived or actual deprivation meted on groups such as the Igbo dominated South-East of Nigeria may strengthen collective identity-based competition and agitations. According to (Chukwuma et al, 2018) identity-based agitations have become a core feature of states in the contemporary world. More so in post-colonial Africa were substantial fractions of identity-based politics of agitation seem to be making waves. The predominantly ethnic driven Biafran agitation by the SouthEasterners in Nigeria, prompted Michael (2015), argued that ethnicity and nationalism (ethnic-civic citizen) in post-cold war Africa have turned out to be the highest indicative parameters responsible for identity-based agitations just as Western Europe in the first half of the 20th century and Asia and Africa in the 1960s. However, ethnic pluralism is a necessary but not sufficient condition for ethnic rife or conflict, the prerequisites implies that ethnic differences are mobilized and manipulated in pursuance of personal or group interests (Osaghae, 1991). Furthermore, Call (2008, p. 63) observes that owing to plausible destabilizing properties of identity, there is a natural predisposition to capitalize on the potency of negative identity to prompt conflict. While this discourse may sufficiently account for the salient aspects of ethnic identity, it has largely fallen short of capturing the mobilizing effects of ethnic identity. In the sense that ethnicity as a social capital can be deployed to numerous ends.

Findings from Afrobarometer survey which examines tolerance toward people from other ethnic, religious and national groups is nearly universal in six West African countries, Nigeria (86\%), Gabon (99\%), Côte d'Ivoire (99\%), Senegal (98\%), Benin (97\%), Togo (97\%), and Liberia (96\%) (Howard, 2020).While acknowledging the potency of ethnic diversity to fuel conflict, by themselves they are not sufficient to stir conflict, given the large number of peaceful multicultural societies (Fearon and Lation, 1996). The data shows despite heightened levels of ethnic awareness, there remains significant levels of tolerance amongst indigenous ethnic groups.

Nonetheless, it is been argued that, ethnic conflicts persist when influential ethnic entrepreneurs who identify with a particular ethnic group, mobilize such ascription for personal or group interests through violent means. 
(Wolff, 2007). The entrepreneural and institutional approach are selfenforcing. In the sense that, the nature and capacity of state institutions play central roles in informing ethnic conflict when, they are unable to effectively sanction inter-ethnic relations and thus control the conflict potential of ethnicity consciousness. The model adopts institutions and political system as explanations of ethnic conflict, or the lack of it. As rightly observed, institutional designs and state policies play a major role in shaping and conditioning ethnic mobilization (Lipset et al, 1993). The interplay between institutional and entrepreneurial approach, stems from a line of thought which maintains; the extent to which ethnic entrepreneurs are able to successfully mobilize group consciousness, is principally informed by political systems/institutional arrangements that sanctions such practice or are unable to prevent it. According to Crawford (1998),. If states provide level playing grounds for resource competition, identity-based politics, like other kinds of political competition, will be legitimate and largely non-conflictual. The inability to regulate inter-ethnic relations provides a perfect condition for ethnic entrepreneurs to exploit ethnic consciousness to mobilize ethnic groups for their own political interests.

Based on the foregoing, it is pertinent to highlight that central to the efficiency of the entrepreneur model are, ethnic heterogeneity, state capacity and policies. Furthermore, the inability of the civil society and class structures to proffer viable interface between the state and society, further strengthens the role of ethnicity. From welfare, collective action and identity, ethnicity continues to play significant roles in informing wealth redistribution in Nigeria. Through institutions such as the Federal Character Principle in Nigeria2 to informal power sharing accords at obtained in party politics in Nigeria, ethnicity is central to who gets what, when and how. Extant manifestation of ethnic instrumentality obtains in constitution of political parties along ethnic and regional lines, quota-based measure for enlistment into civil and public service and social cultural and other welfare organization premised on the basis of ethnic identity. The capitalization of ethnicity derives in amongst other factors from the inability to effectively manage diversity and the rise of ethnic entrepreneurs or elite who mobilize ethnicity as a social capital in the presence of or perceived mutual benefits. Ordinarily, political campaigns and manifestos continue to premise on the basis of emancipation of one's 'people'.

Similarly, Akidiyo (2013) attempts to account for group agitations with ethnic undertone, he claims, ethnicity is underscoredby a common consciousness of being. Often than not, this conciousness defines the boundary of the group that is relevant for understanding ethnic driven agitations at 
different times. Chukwuma (2016) goes further to argue that ethnicity embodies concealed class component. In this sense, it becomes a tool for the elite members of society to hold on to their privileges. In this regards, ethnic elites have cashed in on the social capital inherent in ethnicity, to further group or individual interest. While the study acknowledges the cooperative and competitive dimensions of ethnicity, it notes that, cooperative ethnicity are not necessarily positive. For instance, shared ethnic consciousness can serve as a uniting factor for minority groups as it could also serve as a basis for expelling or excluding minority groups. By and large, the study suggests ethnicity remains one of the key factors on which groups to lay claims to territory, express collective grievances or further collective interest.

Group theorist, Richardson (1993) claims in the presence of mutual purpose or benefit, individuals will if they have to cooperate for the actualization of common good or mutual aspirations, keeping in mind the relative nature of common good or mutual aspirations. While their arguments have been flawed on the basis of neglecting individual rationality, mid-ground theorist such as Schlozman (1995) suggest that we are often motivated to act collectively by our emotions or passion for a cause and Olson's (1965) claims of rationality seems all too insufficient. Similarly, the symbolism ascribed to group membership based on mutual attributes, historical and cultural heritage transform into tangible realities capable of enlisting members to support group action (Vermeersh, 2011 and Akidiyo, 2013). The consciousness of mutual benefits remains a key factor that attracts individuals who share similar cores. Hence, with emphasis on ethnicity as a measure as opposed to the purpose, conflict can thus be classified as been ethnic if it involves identity-based agitation limited to the innate individual need to identify in relation to a group. By implication, it is expected that such conflicts are not driven by competition for scarce resource or any other form of material benefit or advantage in relation to another ethnic group.

\section{Theoretical Framework}

According to Osaghae (2005), ethnicity as a process, involves the mobilization of conscious ethnic diversity to assume vantage positions in cases of competition, conflict or cooperation. Ethnicity epitomizes communal emotional concentration that can be unprecedentedly deployed when group's interests are thought to be endangered (horowitz, 1985). Emotions as obtains remains central to human motivation, they are central to self-identification in relation to a group, they also constitute the social ties that makes groups, societies, or nations, possible (Lang et al, 1998). To account for the inherent misrepresentation of ethnicity, the submissions of the ethnic competition model theorist is herewith adopted as framework for analysis. 
Ethnic competition model builds on Frederick Barth's work (1969), views ethnic conflicts as as outcomes of competition in the presence of ethnicity. They contend intersections in the economic activities of two or more ethnic groups lead to ethnic competition, which in other times has lead to exclusion or deprivation (Juan, 1994; Nagel and Olzak 1982; Olzak et al, 1992)Ethnic competition theory applies both to economically advantaged (Olzak 1992) and economically disadvantaged ethnic groups (Ragin 1979; Olzak 1982; Nielsen 1980). Competition is assumed to be heightened in instances where competing ethnic groups are employed in the same, rather than different, occupations (Ozlak 1992, and Tilly, 1991).

For Ozlak et al, (1982) ethnic mobilization divides as much as it unites. The growth of ethnic politics since the Second World War is best understood when ethnic mobilization is seen as a process of evolving group interests rather than simply the awareness of primordial sentiments. The competitive ethnicity model theorist's inspired instrumentalist (Glickman, 1995; Rokkan, 2005) who also dismiss the symbolist arguments, which ties ethnicity to mutual ancestry, and argue it as a social capital mobilized and employed by political elites (Vermeescsh, 2011). Instrumentalist scholars such as Glickman (1995) see ethnicity as an integral component of political processes. Claiming that regardless of persistence of ethnic conflicts in the politics of all African states, significant liberalization and democratization are possible. Furthermore, (Ramine et al, 2015) are of the opinion that, nation and nationalism as ethnicity are modern phenomena, and invented by the elite and exploited for certain ends (Ramine et al, 2015).

Competitive scholars in their submissions, attempt to emphasize the possibilities of non-violence or conflictual outcomes of ethnic mobilization (Barth, 1969; Ozlak, 1982 and Osaghae, 2005), measured against the universe of possible occurrences, actual manifestations of ethnic and nationalist violence remain uncommon (Brubaker et al, 1998). For them, the root of ethnic conflict is competition among ethnic groups for scarce resources (Juan, 1988). Nonetheless, studies which attempt to highlight the non-conflictual outcomes of ethnic consciousness have received minimal scholarly attention.

For the purpose of this analysis, the study highlights the role of ethniccompetition in driving group and individual political aspirations in Nigeria. For the purpose of this discussion, the seeming competition by various regional interests as it concerns presidential aspiration in Nigeria will be examined. Barely a year after the General Elections in 2019, that saw President Muhammad Buhari of Hausa-Fulani descent re-elected for a second and final term. The, former Chairman of the Alliance for Democracy Party Reverend Okechukwu Christopher Obioha who is the National Coordinator South East for Presidency 2023 Movement (SEFOP2023) granted an exclusive interview to a national daily in which he claims; 
the Southeast for President 2023 Movement (SEFORP2023) is a mass movement that peacefully advocates the election of a President of the Federal Republic of Nigeria from the Southeast in the forthcoming general elections slated for 2023. SEFORP2023 he claims is apolitical, but socio-political peaceful movement that is not affiliated with or funded by any political party or candidate. Our vision is that, by 2023, the President of Federal Republic of Nigeria will come from Southeast. Our mission is to ensure that every political party, especially the two major political parties and/or any third force cede their presidential candidates to the Southeast come 2023. Our conviction is based on the axiom that what is goodfor the goose is also good for the gander. Although zoning of the Presidency between the South and North is not an article of faith, as there is no trace of it in our Constitution, just like the six zonal structures, it has become an acceptable sharing formula. It has become an obvious acceptable norm in our political lexicon (Njoku, 2019, p.2).

It is worthy to note that, the incumbent president from the North, while his vice is from the South-West. Rightly so, their predecessor a Southerner, served as vice to a Northerner before becoming the principal officer to another Northerner. By and large, ceding of the presidency to regions as argued by Obioha constitutes a definite attribute of the Nigerian political turf. In its contemporary history the South Eastern region dominated by the Igbo remains the only major language that has not produced a president. The extant detachment between the South-East and the Nigerian state, contributed to the Biafran civil war. In lieu, it will suffice to claim that, ethnicity transcends beyond the boundaries of identity and has materialized as one of the principal denominations upon which political, social and economic aspirations are prospered. As such, conflicts should not be reduced to primordial strife on the basis of difference in dialect and ancestral origin.

Similarly, one of the influential social organization with a strong support base from the South-Western part of Nigeria, the O'odua People's Congress (OPC) came to existence as a reaction of the Yoruba nation to the annulment of June 1993 presidential elections in which their preffered candidate Moshood Abiola seemingly won (Badmus, 2006). The group was led by youths who feel disenfranchized by a Northern Cabal in the ranks of the Nigerian Army who has denied Abiola his electoral victory (Omotosha, 2009). Although the activities of the OPC was confrontational, this was not a surprise considering Nigerian was under military rule as at the time of their emergence. In recent times however, they have largely identified with the aspirations of promoting the interests of the South Western region under Nigeria's federal arrangement. It is also worthy to note that, with the exception 
of pocket violence the OPC has largely remained non-confontational since the return of democracy in 1999.

Hence, transformational progression from resentment to conflict on the basis of ethnic mindfulness should never simply be regarded as an instinctive linear sequence from cause to conflict. More so because the process of mobilization nonetheless remains a complex, multidirectional and not inevitably convergent or logical process necessitating the centrality of contextual examination. Hence, conflicts with ethnic undertone are unlikely off-the-cuff eruptions of mutual anger and dissent, more often than not, they tend to involve certain levels of conscious organization and planning. It is thought that, ethnic conflict is assumed to manifest when a critical number of influential people undertake calculated decision to pursue their goals and by extension that of groups they identify with or represent through violent means, which is directed towards competing or rival groups (Wolff, 2007, p. 6, Kalu, 2016). ). By implication the influential individuals whom are conventionally ethnic entrepreneurs, are unable to by themselves perpetuate violence without the support of or consent and cooperation of others members who accept such person (s) as a representative or leader.

\section{Conclusion}

The most basic conclusion from the analysis undertaken, suggests that, central to numerous manifestations of ethnicity in contemporary Nigeria is the decision by ethnic entrepreneurs to invoke the mutual consciousness shared by individuals who identify with a particular group. And that in the absence of socio-economic and political competition, symbolic ethnic pluralism is less likely to result in conflictual group relations. This is in addition to the effects of structural arrangements and prevailing social norms. Through policies such as Federal Character Principle, National Youth Service Corps and the likes, the Nigerian states recognizes and reinforces the premium placed on ethnicity. While ethnicity can serve as avenue to mobilize for conflict, competition and corporation, its conflictual dimension has been amplified at the expense of others. The predisposition to vilify ethnicity as the bane of all vices in Nigeria and beyond, remains arguably high.

Often than not, the analysis of ethnicity fall short of capturing the roles played by leadership dynamics and pre-existing social structures on social norms. In the absence of formidable class structures and vibrant civil society, ethnicity remains one of the key determinants of collectivism. Resultantly, the study places premium on measure as opposed to purpose, as such conflict can thus be classified as been ethnic if it involves identity-based agitation limited to the innate individual need to identify in relation to a group. In addition, such conflicts are not driven by competition for scarce resource or any other form of material benefit or advantage in relation to another ethnic group. To this 
end, it is expected that agitations for recognition are properly defined from socio-economic and political competitions with ethnic undertones or determinants, modus operandi and to established goals as opposed to the practice of reducing such to ethnic rife.

Against this, the study takes issue with the seeming predisposition to limit the analysis of ethnicity to conflictual group relations, and those who suggest ethnicity to be the bane of all vices in the developing world. The inability of relevant frameworks to establish the mechanism through which ethnicity in its 'symbolic dimension, strengthens the submissions of the competitive model theorist. Put differently, in the absence of competition, ethnic consciousness is highly unlikely to result in conflictual group relations.

\section{References:}

1. Adeboye, D. A. (2015). Ethno-Religious Conflict and Democracy in Nigeria . Global Journal of Arts \& humanities in Social Science, Vol. 3. No. 1. Pp. 51-58.

2. Adekanya, J. B. (1995). Structural Adjustment, Democratization and Rising Ethnic Tensions in Africa . Development and Change , 2 (26). 355-374.

3. Aghamelu, F. C and Aghamelu, H. U. (2016). Ethnic conflict in Pluralist Nigeria: Entrenching Participatory Democracy . OmoghoNigeria : Centre for Democracy and Human Development Research .

4. Alapiki, H. (2005). State Creation in Nigeria: Failed Approaches to National Integration and Local Autonomy . African Studies Review, Vol. 48. No. 3. Pp. 49-65.

5. Asiyonbola, R. (2010). Ethnic Conflict in Nigeria: A Case of Ifemodakeke in Historical Perspective. Journal of Humanities, Social Science and Creative Arts, Vol. 5. No. 1. Pp. 61-78.

6. Ayatse, F. H and Akwu, T. I. (2013 ). The Origin and Development of Ethnic Politics and its Implication on Post-Colonial Governance in Nigeria . European Scientific Journal , Vol. 9. No. 17. Pp. 178-189.

7. Badmus, I. (2006). Ethnic Militias and Crisis of Political Order in PostMilitary Nigeria . Journal of Social Science, Vol. 13. No. 3. Pp. 191198.

8. Bayrat, J. F. (1993). Politics of the Belly . New York : Longman Publishers.

9. Barth, F. (1969). Ethnic Groups and Boundaries. Boston: Little Brown and Company.

10. Berdal, M. and Malone, D. (2000). Greed \& Grieviances: Economic Agenda's in Civil Wars. Boulder-Colorado : Lynne Reinner . 
11. Belangs, S and Pinard, M. (1991). Ethnic Movement and the Competition Model: Some Missing Links. American Sociological Review, Vol. 56. Pp. 446-457.

12. Breman, B. J. (1998). Ethnicity, Patronage and the African State: The Policitcs of Un Civil Nationalism. African Affairs, Vol. 97 (388). Pp. 305-341.

13. Bojana, B. (2004). Ethnic Conflict and Post Conflict Development: Peace Building in Ethnically Divided Societies. Graduate School of Newark.

14. Remi, C. (2016). Ethnicity, Political Leadership and National Development in Nigeria: The Contradiction and the Local Government Nexus. World Scientific News, WSN 56, Pp. 67-81.

15. Call, C. (2008). Building States to Build Peace? A Critical Analysis . Journal of Peace-Building and Development, Vol. 4. No. 2. Pp. 6074.

16. Caselli, F. a. (2006). On the Theory of Ethnic Conflict. London : London School of Economics Publication .

17. Chukwuma, A. N. (2018). The Nigerian Elite and Dialetics of Identity Politics in Nigeria: A Discourse on Biiafran Agitation . Journal of Humanities and Social Science, Vol. 23. (11). Pp. 63-70.

18. Daniel, E. A. (2011). Unholy Trinity: The Impact of Ethnicity and Religion on National Identity. The Canadian Journal of Peace and Conflict Studies, Vol. 43. No. 2. Pp. 98-125.

19. Davidson, B. (1992). The Black Burden: Africa and the Cause of Nation-State. New York: Times Books.

20. Dibua, J. (2011). Ethnic Citizenship, Federal Character and InterGroup Relation in Postcolonial Nigeria . Journal of History Society of Nigeria, Vol. 20. Pp. 1-25.

21. Duruji, M. (2014). Ethnic Militias and Sub-nationalism in Nigeria: a Comparative Study of MASSOB and OPC. convenant university political science and international relations, Vol. 2. No 1. Pp. 12-26.

22. Ebegbulem, J. C. (2011). Ethnic Politics and Conflict in Nigeria: Theoretical Perspectives. Khazar Journal of Social Science, (14).3. Pp. 76-91.

23. Ekeh, P. (1975). Colonialism and the Two Publics in Africa: A Theoretical Statement . Comparative Study in Sociey and History, Vol. 17. No. 1. .

24. Englebert, P. (2000). Solving the Mystery of the Africa Dummy . World Development, Vo. 28. No. 10. Pp. 1821-1835.

25. Fearon, J. a. (1996). Explaining Inter-Ethnic Coperation . American Political Science Review , Vol. 90. (4). Pp. 715-735. 
26. Franca, A. A. (2011). The Politics of Ethnic Balancing in Nigeria . International Journal of Sociology and Anthropology, Vol. 3. No. 2. Pp. 40-44.

27. Guobadia, A. O. (2004). Ethnicity and National Integration in Nigeria . Lagos : Institute of Advanced Legal Studies .

28. Herman, G. (2009). Ethnic Conflict and Democratization in Africa . Atlanta Georgia : The African Studies Association Press.

29. Hechter, M. (1975). Internal Colonialism: The Celtic Fringe in British National Development, 1536-1996. London : Routledge Publishers.

30. Horowitz, D. (1971a). Three Dimensions of Ethnic Politics . World Politics, 23. (2). .

31. Horowitz, D. (1985b). Ethnic Groups in Conflict. Berkely : University of California.

32. Howard, B. (2020c). All in this Together: African's Tolerance on Ethnic, Religious and National but not Sexual Differences. Afrobarometer Dispatch No. 362, May 19 ${ }^{\text {th }}, 2020$.

33. Imuetinyen, F. (2015). Analysis for Managing Democratic Ethnic Competition and Conflict. The Nigerian Experience . The Journal of Development Area, Vol. 43. No. 2. Pp. 263-272. .

34. Isiaka, A. (2009). Under Reconstruction: Ethnicity, Ethnic Nationalism and the Future of the Nigerian State . Law and Politics in Africa, Asia and Latin America, Vol. 12. No. 2. Pp. 212-239.

35. Juan, W. E. (2011). Artificial States . European Economic Association , Vol. 9. No. 8, Pp. 246-277.

36. Juan, D. M. (1994). The Effects of Ethnic Segregation and Ethnic Conflict on Political Mobilization: Some Missing Links. American Sociological Reviews, Vol. 56. Pp. 446-457.

37. Kalu, P. (2016). Political Parties and Ethnic Politics in Nigeria . Nigerian Journal of Social Development, Vol. 5. No. 2. Pp. 140-153.

38. Lang, P. I. (1998). Emotion, Motivation and Anxiety: Brain Mechanism Psychology. Biological Psychiatry, Vol. 44. Pp. 12481263.

39. Larry, D. (1987). Class, Ethnicity and the Democratic State: Nigeria 1950-1966. Comparative Studies in Society and History, Vol. 25. No. 3. Pp. 457-487.

40. Mandani, M. (1996). Citizen and Subject: Contemporary Africa and the Legacy of Late Colonialism. Princeton : Princeton University Press.

41. Malone, P. (2007). The Control of Politicians in Divided Societies: The Politics of Fear . Review of Economic Studies, Vol. 74. No. 4. Pp. 1259-1274. 
42. Johnston, M. P. (2014). Secondary Data analysis: A Method of Which the Time Has Come. Qualitative and Quantitative Methods in Libraries, Vol. 3. Pp. 619-629.

43. Marie, S. and Gillian, R. (2011). Violently Divided Societies: Ethical and Methodological Issues. Tokyo: United Nations Press .

44. Mariz, N. A. (2016). The Evolution of Ethnicity Theory: Intersectionality, Geopolitics and Development . United Kingdom: Institute for Development Studies .

45. Mbalisi, C. N. (2017). Challenges of Ethnicity, Politics by Identity and Prebendalism to Security and Social Stability in Nigeria, 1999 to 2015. UJAH, Vol. 18. No. 3. Pp. 70-97.

46. Mike, O. (2015). Diagnosing the Interplay of Religious Identity, Elite Hipocrisy and Political Leadership Ascendancy in Nigeria's Fourth Republic . International Journal of Politics and Good Governance, Vol. VI, (6). Pp. 23-37.Vanguard Newspaper, (2011, November 27). The Reality of Competitive Ethnicity in Nigeria . Vanguard Editorial , p. 1 .

47. Nellsen, F. (1980). The Flemish Movement in Belgium after World War II: A Dynamic Analysis. American Sociological Review, Vol. 45. Pp. 76-94.

48. Njoku, L. (2019, October 13). Igbo Presidency is Achievable through Peaceful Negotiations-Obioha. The Guardian , p. 2.

49. Noyoo, N. (2000). Ethnicity and Development in Sub-Saharan Africa . Journal of Social Development in Africa, Vol. 15.No. 2. Pp. 55-67.

50. Nulifer, R. J. (2015). Instrumental and Symbolic Resources of Ethnic conflict: Application to the Kurdish Conflict in Turkey. Illinois : University of Illinois Urbana Campaign .

51. Olayode, K. (2016). Beyond Intracabilit: Ethnic Identity and Political Conflict in Africa . International Journal of Humanities and Social Science, Vol. 6. No. 6. Pp. 242-248.

52. Olson, M. (1965). The Logic of Collective Action . Cambridge MA: Havard University Press.

53. Omotosha, M. (2009). Violent conflict and the Question of Democracy in Nigeria: The Crises of Ethnic Militias. Journal of Legislative Studies , Vol. 1. No. 2. Pp. 115-124.

54. Osaghae, O. E. (1991). A Re-Examination of the Concept of Ethnicity as an Ideology for Inter-Elite Competition . African Study Monograph , 12. (1). Pp. 43-60.

55. Osaghae, O. E and Rotimi, T. S. (2005). A Historical Survey of Identities, Violence and Stability in Nigeria. Crisis Working Paper, No. 6. 
56. Ozlak, S and Nagel, J. (1982). Ethnic Mobilization in New and Old Societies: An Extension of the Cooperation Model. Social Problems, Vol. 30. No. 2. Pp. 127-143.

57. Patrick, E. A. (2014). Managing Ethnic and cultural Diversity for National Integration in Nigeria . Developing Countries Studies, Vol. 4. No. 6. Pp. 70-76.

58. Ray, I. J. (2012). A Historical Survey of Ethnic Conflict in Nigeria. Asian Social Science, Vol. 9. No. 4. Pp. 13-29.

59. Richardson, J. (1963). Pressure Groups . Oxford : Oxford University Press.

60. Rogan, C. (1979). Ethnic Political Mobility: The Welsh Case. American Sociological Review. Vol. 44. Pp. 619-635.

61. Rotchild, D. R. (1988). Politics and Society in Contemporary Africa. Boulder Colorado : Lynne Rienner Publication .

62. Scholozman, K. (1995). Participation not a PAradox: the View from American Activitist. British Journal of Political Science, Vol. 25. No. 1.

63. Soye, P. A and Asawoba, I. B. (2016). Collectivism and Organizational Success. Managing Cultural Diversity in Nigeria's Multicultural Corporation for National Development, $10^{\text {th }}$ Annual Conference of Academy of Management of Nigeria. Ahmadu Bello University, Zairia.

64. Stewart, F. (2009). Religious versus Ethnicity as Source of Mobbilization: are there Differences? Oxford: CRISE Working Paper No. 10, University of Oxford.

65. Suberu, T. (2005). A History of Identity Violence and Stability in Nigeria . Oxford : Queen Elizabeth House CRISS Working Paper. University of Oxford .

66. Tilly, C. (1991). Ethnic Conflict in Soviet Union. Theory and Society. Vol. 20. Pp. 569-581.Ukiwo, U. (2005). The Study of Ethnicity in Nigeria . Oxford Development Studies, Vol. 8. No. 2. Pp. 78-85.

67. Vanguard (2018). The Reality of Competitive Ethnicity in nigeria . Vanguard Editorial.

68. Vermeersch, P. (2011). Theories of Ethnic Moblization:Overview and Recent Trenda. Belgium : Centre for Research on Peace and Development. Working Paper No. 3.

69. Wolff, S. (2007). Ethnic Conflict: A Global Perspective . Oxford : Oxford University Press.

70. Yakubu, Y. (2018a). Ethnicity in Africa: Euphemism for Political Plurrality . International Journal of Research and Innovation in Social Science, Vol. III, Issue. X. Pp. 18-23. 
71. Yakubu, Y. (2019b). Ethnicity and Nationalism in Nigeria: the Paradox of Dual Identity. International Journal of Recent Innovations in Academic Research, Vol. 3. (2). Pp. 25-29. 